\title{
Anxiety And Avoidance: The Mediating Effects Of Computer Self-Efficacy On Computer Anxiety And Intention To Use Computers.
}

Kevin P. Pauli, (E-mail: kpauli@acm.org), Jackson State University

Richard L. Gilson, (E-mail: gilsonr@nku.edu), Northern Kentucky University

Douglas R. May, (E-mail: drmay@ku.edu), University of Kansas

\begin{abstract}
Computer anxiety effect on intention to use computers is discussed. Computer self-efficacy, based on social cognitive theory is suggested as a way to influence avoidance behavior. The mediating effect of computer self-efficacy on individual computer anxiety and intention to use computers is tested. Results indicate that the effects of computer anxiety on intention to use computers are fully mediated by an individual's computer self-efficacy beliefs.
\end{abstract}

\section{INTRODUCTION}

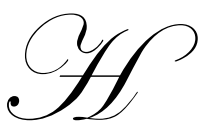

ow can the computer anxious be encouraged to use computers? Many studies have examined the role of anxiety (Glass \& Knight, 1988; Bandalos, Yates \& Christ, 1995; Heinssen, Glass \& Knight, 1987) and self-efficacy (Mitchell, Hopper, Daniels, Falvey \& James, 1994; vanRyn \& Vinokur, 1992) and their effects on computer use and performance (Martocchio 1994; Harrison \& Rainer, 1992; Torkzadeh \& Koufteros, 1994; Igbaria \& Iivari, 1995). There has however, been little research on the mediating effect of computer selfefficacy on computer anxiety and intention to use computers. Anxiety and fear lead to avoidance (Glass \& Knight, 1988) which reduces the anxiety and fear and thus strengthens the avoidance. As the avoidance behavior becomes a function of its anxiety reducing consequences (Kreitner \& Luthans, 1984; Davis \& Luthans, 1980) it is repeated and the activity is avoided. This process has been supported by findings that negative attitudes, fear and anxiety of computers limit use (Igbaria, Schiffman \& Wieckowski, 1994). However, if the process is internal how do we change this avoidance behavior?

Social Learning Theory (Bandura, 1977) and later Social Cognitive Theory (Bandura, 1986, 1991; Wood \& Bandura, 1989) provide that while a behavior is a function of its consequences, it can be changed through cognitive mediation and social learning. Social Cognitive Theory suggests that our own self-regulatory mechanisms can influence the relationship between emotional arousal and our actions or performance, and that these relationships are reciprocal in nature. So a change in any one of the factors could potentially lead to changes in the other factors. The most important self-regulatory mechanism has been identified as self-efficacy which has been found to strongly affect an individual's intentions and behaviors (DeVries, Backbier, Kok \& Dijkstra, 1995; Igbaria et al., 1994; Brubaker \& Fowler, 1990) and has also been highly correlated with anxiety (LaGuardia \& Labbe, 1993; Martocchio, 1994; Harrison \& Rainer, 1992).

Albert Bandura has suggested that self-efficacy can provide incentive to continue an activity even in the face of failure as well as provide an opportunity to change behaviors within the traditional behavior management cycle. This paper will examine the role of application specific computer self-efficacy in mediating the effect of computer anxiety on an individual's intention to use computers. Specifically this paper asks: Does computer self efficacy mediate the relationship between computer anxiety and intention to use computers? 


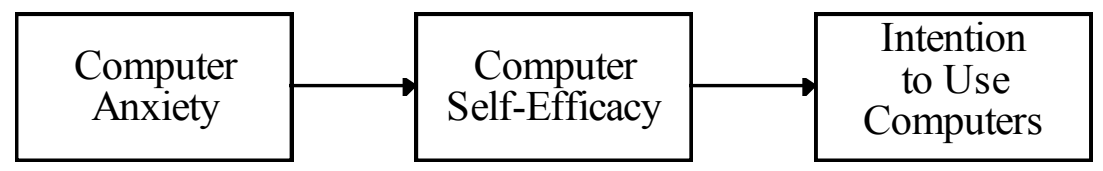

Figure 1: Mediating Effect Of Computer Self-Efficacy.

\section{INTENTION TO USE COMPUTERS}

Information technology requires some way to analyze system acceptance. The Theory of Reasoned Action (TRA) proposed by Fishbein and Ajzen (1975) stated that individual beliefs and attitudes affect behavioral intentions which then influence actual behavior. The concepts within the TRA model were applied to computers in the Technology Acceptance Model (TAM) proposed and tested by Davis, Bagozzi \& Warshaw (1989). In this model, the individual's usage of a computer was determined by his/her intention to use a computer. Intention to use computers has become a standard of computer utilization measurement.

Intentions are defined as "indications of how hard people are willing to try, of how much of an effort they are planning to exert, in order to perform the behavior" (Ajzen, 1991: p. 181). The benefit of examining an individual's intention to perform an activity, or in this case use a computer system, is that the stronger the intention to act, the more likely the action is to occur. This relationship between intention, and actual behavior has been supported in various fields and situations (Davis et al., 1989, 1992; Sheeshka, Woolcott \& MacKinnon, 1993; Brubaker \& Fowler, 1990; DeVries et al., 1995).

\section{ANXIETY}

Anxiety has been found to relate strongly with negative thoughts and negative expectations of success (Glass \& Knight 1988). Computer Anxiety was defined by Igbaria and Parasuraman (1989:p. 375) as the "tendency of individuals to be uneasy, apprehensive, or fearful about current or future use of computers" (cited in Igbaria et al., 1994). Research has found that computer anxiety has a strong negative effect on both the perceived usefulness of computers and on individual's intention to use computers (Igbaria et al., 1994; Compeau \& Higgins 1995). So an individual who is anxious about computers will tend to use them less, but why? Henderson, Deane \& Ward (1995:24) argued that computer anxiety's effect on use is "explained by operant conditioning, such that anxiety is viewed as a drive that motivates the organism to avoid the stimulus for anxiety." The user is rewarded with reduced anxiety by not using a given computer system and the avoidance is perpetuated.

So if the user is being rewarded with less anxiety by avoiding the use of the system how can an organization break through this cycle and raise their usage of the system? This question is critical to actually changing the behavior of avoidance. Studies have found that computer experience provides a strong negative effect upon computer attitudes, including anxiety (Ogletree \& Williams, 1990). Anxiety has also been found to have a high negative correlation with feelings of self-efficacy (LaGuardia \& Labbe, 1993; Henderson et al., 1995; Igbaria et al., 1994). In line with the reciprocal causation model if a user could be provided with behavior modeling, or training, which increases computer self-efficacy and thus computer use, their level of anxiety could be reduced, leading to higher selfefficacy beliefs and higher usage.

\section{COMPUTER SELF-EFFICACY}

Within social cognitive theory (Bandura, 1986, 1991) individual motivation and self regulation processes are controlled through several self-regulatory mechanisms. One of the most important regulatory mechanisms is selfefficacy, which Albert Bandura $(1977,1986,1991)$ defined as:

People's judgments of their capabilities to organize and execute courses of action required to attain designated types of performances. It is concerned not with the skills one has but with judgments of what one can do with whatever skills one possesses (Bandura 1986, p. 391). 
Self-efficacy represents the perceived ability to accomplish a task, rather than simple component skills (Compeau \& Higgins, 1995). Self-efficacy has been found to be a major determinant of performance (Gist, Schwoerer, \& Rosen, 1989; Compeau \& Higgins, 1995; Smith-Jentsch, Jentsch, Payne \& Salas, 1996), related to both the acquisition and transfer of skill (Smith-Jentsch et al., 1996), and positively related to learning (Pajares \& Miller, 1994; Compeau \& Higgins, 1995). Most importantly for this study however, self-efficacy is negatively associated with anxiety (Bandalos et al., 1995; Compeau \& Higgins, 1995), and positively related to future intention to behave (Skeeshka et al., 1993; Brubaker \& Fowler 1990).

The focus of this paper is on a task specific form of self-efficacy termed, "computer self-efficacy", which has been defined as a "an individual's perceptions of his or her ability to use computers in the accomplishment of a task (i.e., using a software package for data analysis, writing a mailmerge letter using a word processor)" (Compeau \& Higgins, 1995: p.191). Computer self-efficacy has been found to have a strong negative correlation with computer anxiety (Compeau \& Higgins, 1995; Martocchio, 1994; Harrison \& Rainer, 1992; Igbaria et al., 1994; Henderson et al., 1995), positive effects on the amount of computer usage (Igbaria \& Iivari, 1995) and the intention to use computers (Compeau \& Higgins, 1995; DeVries et al., 1995). Computer self-efficacy is also positively related to computer experience (Busch, 1995, 1996; Ogletree \& Williams, 1990).

Mediation Effect of Computer Self-Efficacy

Through the reciprocal nature of Social Cognitive Theory (Bandura 1986), an individual's level of selfefficacy is affected by situational factors such as environmental contexts which may negatively influence self-efficacy by increasing personal anxiety through thoughts of failure (Stajkovic \& Luthans, 1999). This emotional arousal may be perceived by the individual as "signs of vulnerability to poor performance" (Wood \& Bandura, 1989: 183). This emotional arousal, however, is only one portion of the factors affecting self-efficacy beliefs.

Self-efficacy is also suggested as a specific task measure of ability (Bandura 1977), while computer anxiety and usage intentions are more general in nature, so an individual who has confidence in his/her ability to perform activities using a specific software package should reduce or eliminate the effect of a general level of computer anxiety in determining his/her intention to use computers. The specific behavioral self-efficacy should fully mediate the effects of the general emotional arousal on the individual's intention to use computers.

Hypothesis 1: Application specific self-efficacy will mediate the relationship between computer anxiety and intention to use computers.

\section{METHODOLOGY}

\section{Participants}

The research design used was a study of 84 undergraduate business students in an introductory computer course in a large idwestern university. Participants completed a questionnaire which included scales on the intention to use computers, computer anxiety, and computer self-efficacy. The mean age of the participants was 22.3 , and their ages ranged from 19 to 69 . The students were predominantly business students (79\%). The mean education level was Sophomore in college (39\% Freshmen, 34\% Sophomore, 18\% Junior, 9\% Senior), 46\% were female, and average GPA 3.06.

The students within the mandatory computer class were familiar with computers in general (average years of experience 3-4, 53\% reported owning computers). Thus, the students in this class provided a group of computer users who were familiar with computers, and thus have had an opportunity to develop anxiety beliefs, and were being continually confronted with requirements to use computers in a wide variety of situations.

\section{Procedures}

Students in three sections of an introductory computer class were given instructions regarding a survey investigating "human-computer interaction." Participation was voluntary and assurances were provided regarding the 
confidentiality of any specific material collected. Questionnaires were distributed to students, who completed the first survey (Computer Anxiety \& Excel Self-Efficacy) prior to any instruction on Microsoft Excel and the second survey (Intention to Use Computers) after taking the examination on Microsoft Excel, approximately 5 weeks after the first survey. The total number of available students for both time periods was 114 of these 84 completed the survey and returned them. This resulted in a response rate of $74 \%$. Students who completed the surveys were awarded extra credit points, those choosing not to participate were given an in-class extra credit exercise of the same value.

\section{Measures}

Intention to Use Computers. Intention to use computers was measured with three items developed for this study ( $\left.\propto^{\prime} .79\right)$ on a 5 point Likert scale, with responses ranging from 1 (Disagree strongly) to 5 (Agree Strongly). Questions were designed to reflect the nature of the participants usage: "I plan to use computers in my coursework; I intend to use computers regularly in my coursework; I will use computers in my coursework in the future."

Computer Anxiety Computer anxiety was measured with three items based on the CAS scale developed by Harrison \& Rainer (1992) ( $\propto^{\prime}$ 0.90) participants marked their responses on a 5 point Likert scale, with responses ranging from 1 (Disagree strongly) to 5 (Agree Strongly). Questions were designed to reflect individuals feelings of computer anxiety: "I hesitate to use a computer for fear of making mistakes that I cannot correct; I have avoided computers because they are unfamiliar and somewhat intimidating to me; I am apprehensive about using a computer because I am afraid of feeling foolish.”

Computer Self-Efficacy. Computer self efficacy was measured with the ten item Computer Self-Efficacy scale developed by Compeau \& Higgins (1995), changed to reflect Excel specific items ( $\left.\propto^{\prime} 0.90\right)$. A sample of the questions used is attached in the Appendix.

Control Variables. Previous computer experience was gathered with a self report measure of the number of years of computer experience the user had. It has been suggested that previous computer experience is a predictor of computer anxiety (Henderson et al., 1995) The measure had five levels ranging from " $0-1$ year" through "more than 5 years." Previous computer experience has been found to affect individual's perceptions of usefulness and its effect on intentions to use computers (Taylor \& Todd, 1995). Computer ownership and Previous spreadsheet experience were collected with a two item measure 1 ' no, 2 ' yes.

\section{RESULTS}

The means, standard deviations, and correlations among the variables in the study are shown in Table 1. As shown in the table the students reported relatively low levels of computer anxiety, moderate levels of computer selfefficacy, and relatively high levels of intention to use the computer in the future. The correlation matrix also supports the strong negative relationship between Computer Anxiety and Computer Self-Efficacy (-0.46) and Intention to Use Computers (-0.34).

Table 1

Means, Standard Deviations, And Intercorrelations Among All Variables

\begin{tabular}{lccccccc}
\hline & Variable & $\mathrm{M}$ & $\mathrm{SD}$ & 1 & 2 & 3 & 4 \\
\hline 1. CE & 4.37 & 0.93 & & & & \\
2. CO & 1.52 & 0.57 & 0.18 & & & \\
3. SSE & 1.70 & 0.53 & $0.25^{*}$ & $0.28^{* *}$ & & \\
4. CSE & 3.31 & 0.69 & $0.37^{* *}$ & 0.15 & $0.37^{* *}$ & $-0.46^{* * *}$ & \\
5. Computer Anxiety & 2.22 & 0.97 & $-0.25^{*}$ & -0.12 & -0.21 & $0.36^{* *}$ & $-0.34^{* *}$ \\
6. Intention to Use & 4.04 & 0.67 & 0.05 & 0.12 & 0.11 & \\
\hline
\end{tabular}

Note: $\mathrm{n}$ ' 84, ${ }^{*} \mathrm{p}<.05 .{ }^{* *} \mathrm{p}<.01 .{ }^{* * *} \mathrm{p}<.001$. CE ' Computer Experience. CO ' Computer Owner. SSE ' Spreadsheet Experience. CSE ' Computer Self-Efficacy. 


\section{Regression Analysis}

To examine the effects of Computer Anxiety on Computer Self-Efficacy and Intentions to Use Computers, hierarchical regressions were conducted.

Table 2

Hierarchical Regression Results For The Effects Of Computer Anxiety Dependent Variable

\begin{tabular}{|c|c|c|c|c|c|c|c|}
\hline \multirow[t]{2}{*}{ Step } & \multirow{2}{*}{$\begin{array}{c}\text { Independent } \\
\text { Variable }\end{array}$} & \multicolumn{3}{|c|}{ Computer Self-Efficacy } & \multicolumn{3}{|c|}{ Intention to Use } \\
\hline & & $\beta$ & $\mathbf{R}^{2}$ & $\Delta \mathbf{R}^{2}$ & $\beta$ & $\mathbf{R}^{2}$ & $\Delta \mathbf{R}^{2}$ \\
\hline \multirow[t]{3}{*}{ Step 1} & $\mathrm{CE}$ & 0.37 & & & 0.05 & & \\
\hline & $\mathrm{CO}$ & 0.09 & & & 0.11 & & \\
\hline & SSE & 0.29 & $0.22 * * *$ & $0.22 * * *$ & 0.07 & 0.02 & 0.02 \\
\hline Step 2 & Computer Anxiety & $-0.36 * * *$ & $0.33 * * *$ & $0.12 * * *$ & $-0.33 * *$ & $0.12 *$ & $0.10 * *$ \\
\hline
\end{tabular}

Note: $\mathrm{n}^{\prime} 84 .{ }^{*} \mathrm{p}<.05 .{ }^{* *} \mathrm{p}<.01 .{ }^{* * *} \mathrm{p}<.001$. Standardized beta coefficients listed are the regression coefficients at each step of the equation. CE ' Computer Experience. CO ' Computer Owner. SSE = Spreadsheet Experience.

Table 3

Hierarchical Regression Results For The Effects Of Computer Self-Efficacy (Cse)

Dependent Variable

\begin{tabular}{ccccc}
\hline Step & $\begin{array}{c}\text { Independent } \\
\text { Variable }\end{array}$ & $\boldsymbol{\beta}$ & $\begin{array}{c}\text { Intention to Use } \\
\mathbf{R}^{\mathbf{2}}\end{array}$ & \multicolumn{1}{c}{$\mathbf{R}^{\mathbf{2}}$} \\
\hline Step 1 & CE & .05 & & \\
& CO & .11 & .02 & .02 \\
Step 2 & SSE & .07 & $.14^{*}$ & $.12^{* *}$ \\
\hline
\end{tabular}

Note: $\mathrm{n}=84 . * \mathrm{p}<.05 . * * \mathrm{p}<.01 . * * * \mathrm{p}<.001$. Standardized beta coefficients listed are the regression coefficients at each step of the equation. $\mathrm{CE}=$ Computer Experience. $\mathrm{CO}=$ Computer Owner. $\mathrm{SSE}=$ Spreadsheet Experience. $\mathrm{CSE}=\mathrm{Computer}$ Self-Efficacy.

Table 4

Hierarchical Regression Results For The Mediating Effects Of Computer Self-Efficacy (Cse) Dependent Variable

\begin{tabular}{ccccc}
\hline Step & $\begin{array}{c}\text { Independent } \\
\text { Variable }\end{array}$ & $\beta$ & $\begin{array}{c}\text { Intention to Use } \\
\mathbf{R}^{\mathbf{2}}\end{array}$ & $\Delta \mathbf{R}^{\mathbf{2}}$ \\
\hline Step 1 & CE & -0.10 & & \\
& CO & 0.07 & 0.01 & 0.01 \\
Step 2 & SSE & -0.04 & $0.14^{* *}$ & $0.13^{* *}$ \\
Step 3 & CSE & $0.36^{* *}$ & 0.18 & 0.04 \\
\hline
\end{tabular}

Note: $\mathrm{n}=84 . * \mathrm{p}<.05 . * * \mathrm{p}<.01 .{ }^{* * *} \mathrm{p}<.001$. Standardized beta coefficients listed are the regression coefficients at each step of the equation. $\mathrm{CE}=$ Computer Experience $. \mathrm{CO}=$ Computer Owner. $\mathrm{SSE}=$ Spreadsheet Experience. $\mathrm{CSE}=\mathrm{Computer}$ Self-Efficacy.

Hypothesis 1 was supported. The effect of computer anxiety on intention to use computers was mediated by computer self-efficacy. The results are presented in Table 2 - 4. Baron and Kenny (1986) propose a four step test to indicate mediation. (1) The independent variable must affect the mediator in the first equation. In the test of Hypothesis 1, Computer Anxiety has a significant effect on Computer Self-Efficacy $\left(\Delta \mathrm{R}^{2}=.1185, \mathrm{~F}(1,84)=14.049\right.$, $\mathrm{p}<.001$ ), supporting the test of equation one (Table 2); (2) The independent variable must affect the dependent variable in the second equation. In the test of Hypothesis 1, the effect of Computer Anxiety on Intention to Use computers was significant $\left(\Delta \mathrm{R}^{2}=.1019, \mathrm{~F}(1,84)=9.163\right.$, $\left.\mathrm{p}<.01\right)$, supporting the test of equation two (Table 2); (3) The mediator must affect the dependent variable in the third equation. The effect of Computer Self-Efficacy on Intention to Use was significant $\left(\Delta \mathrm{R}^{2}=.1199, \mathrm{~F}(1,84)=11.016, \mathrm{p}<.01\right)$, in support of equation three (Table 3); (4) Finally, the effect of the independent variable on the dependent variable must be reduced to non-significance with the control of the mediator, if full mediation is to be supported. In the final test of mediation, the effect of Computer Anxiety on Intention to Use computers is reduced to non-significance after controlling for the effect of Computer SelfEfficacy $\left(\Delta \mathrm{R}^{2}=.008, \mathrm{~F}(2,84)=3.817\right.$, n.s.), supporting the mediation and Hypothesis 1 (Table 4). 


\section{DISCUSSION}

The effect of computer anxiety on intention to use computers was fully mediated by the individual's application specific level of computer self-efficacy. This supports the original model of social cognitive theory which argued that the effects of emotional arousal change self-efficacy beliefs and that the primary determinant if behavioral intentions is self-efficacy beliefs. The effect of both self-efficacy and computer anxiety on intention to use computers also provides support for the causal assumptions of the model. The intention to use computers was measured after the Excel instruction was complete and exams taken, and yet still the individual's computer self-efficacy beliefs and computer anxiety were significant determinants of intention to use computers, explaining (12\%) of the variance.

The finding of this paper provide help and guidance for those wishing to increase use of computer systems by users or attempting to change user avoidance behavior. Research shows that mastery experiences, modeling (Bandura, 1977; Wood \& Bandura, 1989), and actual usage (Compeau \& Higgins, 1995; Igbaria \& Iivari, 1995) can positively affect a person's computer self-efficacy which will then help to reduce the computer avoidance behavior of users with high computer anxiety. So users who are computer anxious can be provided with additional computer mastery, modeling and use opportunities, to help increase their future use and reduce their computer anxiety. Alternatively, other research has shown that self-efficacy may be positively affected by expert support (Igbaria \& Iivari, 1995). This second method of efficacy modification suggests that organizations may be able to reduce the avoidance behaviors of users who are highly computer anxious by making task specific expert assistance available to the users. Thus helping to increase the confidence and self-efficacy expectations of the individual user.

\section{Limitations And Future Research}

This study does have several limitations. First the measures of computer self-efficacy and computer anxiety were collected in a cross sectional survey, however factor analysis shows that although Computer Self-efficacy and Computer Anxiety are strongly correlated they are distinct constructs. The interactions proposed by the social cognitive theory suggest that the variables will interact in a reciprocal manner, the model tested focused on a unidirectional causation in order to study the mediation effects of self-efficacy. While the literature and theory support the causal assumptions found the design does not allow for a causal determination between the variables. While future research should continue to investigate the relationships among the variables to verify the causal relationships, the reciprocal nature of the social cognitive theory suggests that the causal directions are unimportant, as a change in one variable can affect all the variables.

\section{CONCLUSION}

It would appear that computer self-efficacy could provide an opportunity to reduce the effect of computer anxiety and avoidance on an individual's intentions to use computers. Through training and positive specific usage experiences it would seem that the effects of computer anxiety can be controlled. This should provide some course of action for those teachers, trainers, system administrators, and managers faced with users who because of fear or anxiety are avoiding using the computer systems.

\section{REFERENCES}

1. Ajzen, I \& Fishbein, M. (1977). Attitude-behavior relations: A theoretical analysis and review of empirical research. Psychological Bulletin, 84, 888-918.

2. Ajzen, I. (1991). The theory of planned behavior. Organizational Behavior and Human Decision Processes, 50, 179-211.

3. Bandalos, D., Yates, K. \& Thorndike-Christ, T. (1995). Effects of Math Self-Concept, Perceived Selfefficacy, and Attributions for Failure and Success on Test Anxiety. Journal of Educational Psychology, 87, 611-623.

4. Bandura, A. (1991). Social Cognitive Theory of Self-Regulation. Organizational Behavior and Human Decision Processes, 50, 248-287.

5. Bandura, A., (1977) Social Learning Theory. Englewood Cliffs NJ:Prentice Hall. 
6. Bandura, A., (1986). Social Foundations of Thought and Action. Englewood Cliffs, NJ:Prentice Hall.

7. Bandura, A., (1997). Self-efficacy: The exercise of control. New York:Freeman.

8. Baron, R. M. \& Kenny, D. A. (1986). The Moderator-Mediator variable distinction in social psychological research: conceptual, strategic, and statistical considerations. Journal of Personality and Social Psychology, 51, 1173-1182.

9. Brubaker, R. G. \& Fowler, C. (1990) Encouraging college males to perform testicular self-examination: evaluation of a persuasive message based on the revised theory of reasoned action. Journal of Applied Social Psychology, 17, 1411-1422.

10. Busch, T. (1995). Gender differences in self-efficacy and attitudes towards computers. Journal of Educational Computing Research, v. 12(2). 147-158.

11. Busch, T. (1996). Gender, group composition, cooperation, and self-efficacy in computer studies. Journal of Educational Computing Research, v. 15(2). 125-135.

12. Chisholm, D. C. \& Hurley, J. D. (1994). Personality Traits Associated With Fear. Psychological Reports, 74, 847-850.

13. Compeau, D. \& Higgins, C. (1995). Computer Self-Efficacy: Development of a Measure and Initial Test. MIS Quarterly, 189-211.

14. Davis, F. D., Bagozzi, R.P., \& Warshaw, P.R. (1989). User acceptance of computer technology: a comparison of two theoretical models. Management Science, 35, 982-1003.

15. Davis, F. D., Bagozzi, R.P., \& Warshaw, P.R. (1992). Extrinsic and intrinsic motivation to use computers in the workplace. Journal of Applied Social Psychology, 22, 1111-1132.

16. Davis, T. R. \& Luthans, F. (1980). A social learning approach to organizational behavior. Academy of Management Review, v.5, 281-290.

17. DeVries, H., Backbier, E., Kok, G., \& Dijkstra, M. (1995) The impact of social influences in the context of attitude, self-efficacy, intention, and previous behavior as predictors of smoking onset. Journal of Applied Social Psychology, 25, 237-257.

18. Fishbein, M. \& Ajzen, I. (1975). Belief, attitude, intentions and behavior: an introduction to theory and research. Addison-Wesley, Boston: MA.

19. Gist, M., Schwoerer, C., \& Rosen, B. (1989). Effects of Alternative Training Methods on Self-Efficacy and Performance in Computer Software Training. Journal of Applied Psychology, 74, 884-891.

20. Glass, C. R. \& Knight, L. A. (1988). Cognitive factors in computer anxiety. Cognitive Therapy and Research, v. 12, 351-366.

21. Harrison, A. W. \& Rainer, R. K., Jr. (1992). An examination of the factor structures and concurrent validities for the computer attitude scale, the computer anxiety rating scale, and the computer self-efficacy scale.

Educational and Psychological Measurement, v. 52, 735-742.

22. Heinssen, R.K., Glass, C.R., \& Knight, L.A. (1987). Assessing Computer Anxiety: Development and Validation of the Computer Anxiety Rating Scale. Computers in Human Behavior, 3, 49-59.

23. Henderson, R.D., Deane, F. P., \& Ward, M. J. (1995). Occupational differences in computer-related anxiety: implications for the implementation of a computerized patient management information system. Behaviour \& Information Technology, v. 14, 23-31.

24. Igbaria, M. \& Iivari, J. (1995). The Effects of Self-Efficacy on Computer Usage. Omega Journal of Management Science, 23, 587-605.

25. Igbaria, M., Schiffman, S.J., \& Wieckowski, T.J. (1994). The respective roles of perceived usefulness and perceived fun in the acceptance of microcomputer technology. Behaviour \& Information Technology, 13, 349-361.

26. Kreitner, R. \& Luthans, F. (1984). A social learning approach to behavioral management: radical behaviorists "mellowing out". Organizational Dynamics, 47-65.

27. LaGuardia, R. \& Labbé, E. E. (1993). Self-efficacy and anxiety and their relationship to training and race performance. Perceptual and Motor Skills, v77, 27-34.

28. Luthans, F. (1998). Organizational Behavior. (8th ed.) Dubuque, IA: Irwin McGraw-Hill.

29. Martocchio, J. (1994). Effects of conceptions of ability on anxiety, self-efficacy, and learning in training. Journal of Applied Psychology, 79, 819-825.

30. Mitchell, T. R., Hopper, H., Daniels, D., George-Falvy, J., \& James, L.R. (1994). Predicting self-efficacy and performance during skill acquisition. Journal of Applied Psychology. v. 79. 506-517. 
31. Ogletree, S. M. \& Williams, S. W. (1990). Sex and sex-typing effects on computer attitudes and aptitude. Sex Roles, v. 23, 703-712.

32. Pajares, F. \& Miller, M. D. (1994). Role of Self-Efficacy and Self-Concept Beliefs in Mathematical Problem Solving: A Path Analysis. Journal of Educational Psychology, 86, 193-203.

33. Sheeshka, J. D., Woolcott, D. M., \& MacKinnon, N. J. (1993). Social cognitive theory as a framework to explain intentions to practice healthy eating behaviors. Journal of Applied Social Psychology, 23, 1547-1573.

34. Smith-Jentsch, K. A., Jentsch, F. G., Payne, S., \& Salas, E. (1996). Can Pretraining Experiences Explain Individual Differences in Learning? Journal of Applied Psychology, 81, 110-116.

35. Stajkovic, A. \& Luthans, F. (1998). Social cognitive theory and self-efficacy: going beyond traditional motivational and behavioral approaches. Organizational Dynamics, 26, 62-74.

36. Taylor, S. \& Todd, P. (1995). Assessing IT usage: the role of prior experience. MIS Quarterly, Dec, 561571.

37. Torkzadeh, G. \& Koufteros, X. (1994). Factorial validity of a computer self-efficacy scale and the impact of computer training. Educational and Psychological Measurement, v. 54, 813-821.

38. Van Ryn, M. \& Vinokur, A. D. (1992). How did it work? an examination of the mechanisms through which an intervention for the unemployment promoted job-search behavior. American Journal of Community Psychology, v. 20, 577-597.

39. Wood, R. \& Bandura, A. (1989). Social Cognitive Theory of Organizational Management. Academy of Management Review, 14, 361-383. 